\title{
Gyermekek a látható világban
}

\author{
Pénzes Dávid*
}

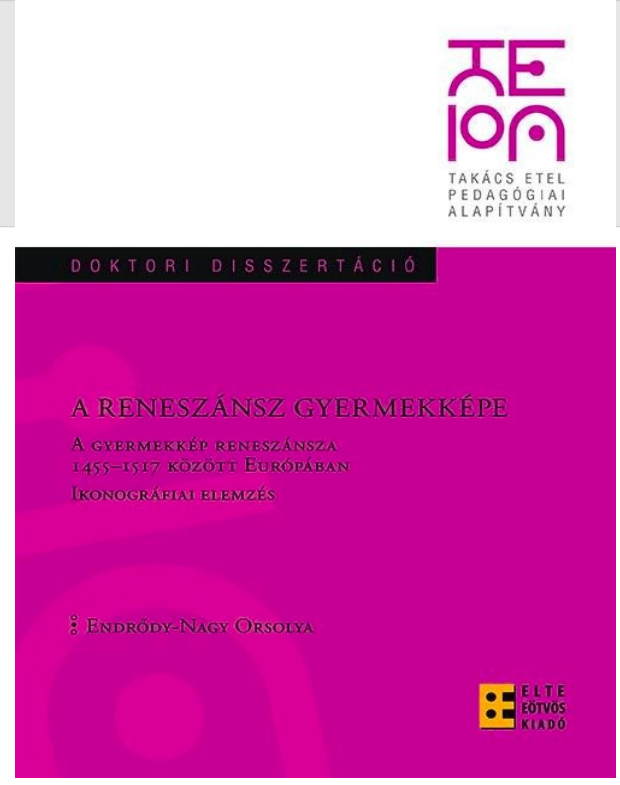

Endrödy-Nagy Orsolya (2015): A reneszánsz gyermekképe. A gyermekkép reneszánsza 1455-1517 között Európában. Ikonográfiai elemzés. ELTE Eötvös Kiadó - Takács Etel Pedagógiai Alapítvány, Budapest.

Alighanem a hazai neveléstörténeti kutatások egyik legprogresszívebben fejlődő iránya az ikonográfiai/ikonológiai megközelítésen alapuló forráselemzés. Ez a közhelyes megállapítás még akkor is igaz, ha eddig - elsősorban - a neveléstörténet vette hasznát és állította csatasorba az új módszert, tovább finomítva a már eddig meglévő gyermekképpel gyermekkor-kutatással kapcsolatos kutatásokat (például: Szabolcs, 1999; Pukánszky, 2001, 2005; Golnhofer és Szabolcs, 2005; Kéri és Varga, 2006; Géczi és Darvai, 2010; Szabolcs, 2011; Darvai, 2011; Golnhofer és Szabolcs, 2012; Somogyvári, 2012, 2013, 2015). A kötet a szerző doktori disszertációján alapul ' és - szemben a megszokott tudományos szövegekkel - sok-sok színes ábrát és képet tartalmaz, melynek okán már-már albumszerűvé teszi a korántsem egyszerű olvasmányt. Endrődy több tanulmányt is közölt már korábban a reneszánsz gyermekképkutatással kapcsolatban (Endrődy-Nagy, 2013a, 2013b), sőt szerkesztőként egy teljes lapszámot is szentelt a képkutatásnak. ${ }^{2}$

Endrődy szigorúan meghúzza és megindokolja az általa kutatott korszak pontos határait. Ezt elsősorban a szakirodalommal indokolja, tulajdonképpen egy ưrt tölt be, ahogy a 3. fejezetből kiderül. A korszakhatár meghúzása, ezáltal pedig a kutatás időbeli lehatárolása kiemelt fontosságú a történeti kutatásokban, amelynek indoka, hogy megszaporodtak az egyes történeti korszakokról szóló munkák, ami nem csak új ismeretek felszínre kerülését jelentette, hanem a megváltozott nézőpontoknak köszönhetően megváltozott a korszakhoz való viszony is, ez pedig tovább finomíthatja egy-egy korszak felosztását. A szerző három oldalon keresztül (!) ismerteti azon jelentős szerzőket és munkásságukat, akik a reneszánsz fogalom-meghatározásával és korszakolásával foglalkoztak (19-22. oldal). A szövevényes szakirodalom áttekintését egy táblázat segít megérteni (17. oldal).

A szerző már az írása elején hangsúlyozza, hogy sok más szempontból is lehetne elemezni a korszakot, de ahogy írja azok „a disszertáció szempontjából nem relevánsak” (11. oldal) majd utána - lábjegyzetben - felsorolja a lehetséges nézőpontokat: néprajzi, esztétikai stb. Még ebben a fejezetben remekül bemutatja a kutatás céljait és a kutatás során alkalmazott metodikát, Pukánszky (vö. Pukánszky, 2005. 9-10.) nyomán pedig különbséget tesz a "gyermekkép" és a "gyermekfelfogás" fogalma között.

De nem csak a fogalom- vagy korszakhatárral kapcsolatban alapos a szerző. Véleményem szerint remekül találta el a képek típusainál - pontosabban a vizsgált képfajták esetében - az „arányokat”: vagyis a képek jelentő ségére és azok technikájára vonatkozó ismertetéseket. Ez ugyan "jelentéktelennek" tűnhet elsőre, ám a képek

* Az ELTE PPK Neveléstudományi Doktori Iskolájának doktorjelöltje, kollégiumi nevelőtanár. E-mail: penzes_david@yahoo.com

1. A doktori értekezés elérhetősége: URL: http://www.doktori.hu/index.php?menuid=193\&vid=14769 Utolsó letöltés 2016. július 25.

2. Lásd a Gyermeknevelés című folyóirat 2017. évi első számát. http://gyermekneveles.tok.elte.hu/ 
készítésének technikája ${ }^{3}$ hatással van a végeredményre is, ugyanis megszabja a „korlátokat" a művész - és az utókor véleményének/ítéletének - számára.

Endrődy bemutatja a nyomtatás forradalmát is ${ }_{1}{ }^{4}$ jelezve, hogy mennyire előtérbe került általa a betü, amely "megfosztva monopóliumától a képet mintegy fétissé válik" (27. oldal). Vagyis az elsődleges forrásként használt kép ekkor kezd másodlagossá válni, ekkor kezdi kiszorítani a betű a "tiszta képet". És azt gondolom, hogy itt már jeleznie kellett volna, hogy a képek olvasását felejtettük el a betűk által, vagy egy újfajta „képolvasás” vette kezdetét? Azt gondolom, hogy valamennyire mindkettő, de Endrődy mégiscsak a képek mintegy újraolvasásával gyermekképpé alakításával - próbálta meg új jelentéstartalommal - vagy a képek egyik lehetséges jelentéstar talmával - felruházni őket. Az olvasás pedig kiszorítva a képet, priori forrássá válik az emberiség számára. Ugyanakkor a szerző a guttenbergi fordulat bemutatásakor (20. oldal) nem domborítja ki - tulajdonképpen meg sem említi - annak a technikatörténetével kapcsolatos vitáját. ${ }^{5}$

A korszak hátterének megvilágításához elsősorban a történeti demográfia eredményeit használja fel. Kiemelten foglalkozik Andorka Rudolf eredetileg 1985-ben megjelent tanulmányával amely a nagy pestisjárványokról szól. A járványokat ugyanis elsősorban az öregek és a gyerekek szenvedték el és ez visszahatott a gyermekről vallott felfogásra és a gyermekábrázolásra is. A pestis - a "fekete halál" - kapcsán továbbá szót ejt - Andorkára hivatkozva - a zsidó pogromokról is (a járványok miatt sokszor a zsidókat okolták), amelynek következtében sok zsidó menekült Lengyelországba és Litvániába (30. oldal).

A dolgozat 5. nagy fejezete az interdiszciplináris keretekkel foglalkozik. Vagyis a munkáját elhelyezi a tudományos erőtérben, illetve bemutatja a szerző azokat a tudományos elméleteket (és a 6. fejezetben a módszereket), amelyek megadták a vizsgálódás elméleti kereteit. Itt számtalan kurrens felfogásról szót ejt Endrődy, így a nyelvi fordulatról a hermeneutika kapcsán (37. oldal), a mikrohistóriáról (38. oldal), a neveléstörténet szempontjából a gyermekképpel - a máig megkerülhetetlen - Ariès-féle megközelítéssel és annak Heywood-féle „továbblépésével" (40-41. oldal) és reflektál még DeMause és Linda Pollock gondolataira is. A vizuális kommunikáció kapcsán Gadamert idézve állítja, hogy a képeket "nem pusztán látjuk, hanem olvassuk" (50. oldal). Rose nyomán pedig a vizuális kommunikáció kutatási rétegeiről beszél, amely ugyanis módszertani szempontból nézve az kutatásának egyik legfontosabb eleme volt(51. oldal). Érdekes módon a vizuális kommunikációval és a(z újfajta) „kép-olvasás” elméleti hátterével keveset foglalkozik a szerző, ami meglepő, hogy ezen új források és technikák kritikájáról egyáltalán nem olvashatunk. ${ }^{\circ}$ Úgy vélem, hogy ez a fejezet leginkább felvillant a kapcsolódó tudományágakból elemeket, mondhatni: szemezget a felhalmozott diszciplináris tudásból (időnként - megítélésem szerint - aránytalanul), leginkább azokból, amelyek a szerző elemző logikája szerint összefüggnek. A hermeneutikáról szóló alfejezetnél (36-38. oldal) sok szerzőtől olvashatunk 1-1 gondolatot, de úgy érzem, hogy kissé felületesen kapcsolta össze a szerzők gondolatait. Miközben örvendetes, hogy nem megy vissza Arisztotelészig, itt például Heidegger-t és Gadamer-t vagy éppen Derridátnem említeni mégiscsak meglepő. Márpedig a hermeneutika velük kezdődött el igazán.

3. Ebben a korszakban még nem voltak képesek gyufafejekre szobrokat faragni vagy éppen „miniatür szobrokat” készíteni (lásd Akinobu Izumi és Chen Forng-shean szobrait).

4. Természetesen nemcsak a könyvnyomtatásról, hanem a könyvek kultúrtörténeti jelentőségéről, státusszimbólum voltáról is ír a szerző.

5. Ez persze valamelyest vitatható, hiszen már a dolgozat elején jelzi, hogy több szempontot lehetne érvényesíteni, mint amennyit ő felhasznált.

6. Nyilvánvaló, hogy a képek új forrásként való értelmezése újfajta olvasást (vagyis értelmezést) igényel, mondhatni olyan ez, mint amikor valaki megtanul egy idegen nyelvet: elsajátítja annak grammatikáját és a szókincsének egy részét. 
A neveléstörténeti vonatkozásnál a nemzetközi és a hazai szerzők műveit is áttekinti, a vizuális kommunikáció kapcsán pedig nem felejti el bemutatni a "képi fordulat"-ot. Azon olvasóknak, akik a művészettörténet órákat kissé unalmasak találták, kifejezetten ajánlott a „Színelmélet" alfejezet többszöri elolvasása: röviden tömören érthetően mutatja be a színkeverési technikákat (itt sajnos két - a nyomdaiparban napjainkban is használt - angol rövidítés az RGB és a CMYK nem kerül feloldásra (64. oldal)) és a színek jelentését is (65. oldal). Ennek az alfejezetnek az elején forráskritikával is él a szerző, felhívja a figyelmet Király Sándor szakmai szempontból kiváló jegyzetének marxista elfogultságára (63. oldal). A fejezet végén "Lehetséges vizuális elemzési megközelítések" (73 oldal) alfejezetben számba veszi a kurrens képelemzés három fő irányát: a vizuális antropológiát, a vizuális szociológiát és az ikonográfiát. Jean Baudrillard-ra hivatkozva szót ejt arról, hogy miért nehéz forrásként használni a képeket (81. oldal).

Az interdiszciplináris keretek után a szerző bemutatja az elemzése során alkalmazott kutatási módszereket. ${ }^{7}$ A kvalitatív és kvantitatív módszerek táblázatos összehasonlítása (86. oldal) jól rávilágít a hasonlóságokra és a különbségekre, ugyanakkor nem tesz hozzá új szempontot a már eddig is ismert kétféle metodikához. Fontos megjegyezni, hogy Endrődy Sántha Kálmán nyomán bevezeti az abdukció fogalmát az induktív és deduktív fogalmak mellé (51. oldal). Itt ugyan kicsit részletesebben fejti ki, hogy a festmények és a fotográfiák miért lehetnek alkalmasak arra, hogy gyermekkor-történeti forrásként tekintsünk rájuk, de egy részről a komolyabb kritikától tartózkodik és a módszertanból is inkább csak felvillant elemzési technikákat. Mindebből arra vonatkozóan nem lehet megállapítást tenni, hogy a szerző itt azért járt-e el így, mert a képelemzés mint tudomány még meszsze nem kristályosodott ki és ebből fakadóan még nem vált teljesen elfogadottá, vagy pedig jobban érdekelte a történeti-filozófiai olvasat. Utóbbi sem elhanyagolható, hiszen a módszertani rész elméleti alapozásának nélkülözhetetlen része.

Külön ki kell emelni, hogy Endrődy kísérletet tesz saját módszer kialakítására. Azért nevezhető kísérletnek, mert korántsem egyértelmű, hogy a képek és a valóság miként tükröződnek egymásban. A saját módszer lényege, hogy a különféle képelemzési technikákat egyszerre alkalmazza, a képeket sorozatokba rendezi és ezzel lényegében véve a saját "(kép)leíró nyelvét" alkotja meg. A szokatlanul rövid - egyoldalas - elméleti bevezető után máris egy gyakorlati példán mutatja be a saját elgondolását (90-94. oldal). A saját módszert követő alfejezetek két szempontból is érdekesek: egyrészről nyomon követhető a szerző forrásválasztása, másrészről pedig bemutatja saját kutatásának történetét (Mészáros, 2014. 15.), ${ }^{8}$ történetesen azt, hogy milyen katalógusokon keresztül jutott el végül a későbbiek során elemzett képekhez, amihez pedig - érzésem szerint kissé didaktikusan a különféle képtípusok és a képek forrásaként használható kódexek definícióját is felhasználja.

Heywood nyomán négy fő témát és azon belül altémát - születés (fogantatás és terhesség, szülés, császármetszés), a csecsemők élete (szoptatás, pólyázás, tisztaság), betegség és halál (gyermekhalandóság, a halálhoz való viszony) és végül a játék - jelöl meg, amelyek mentén tematikus rendbe sorolja az általa elemzett képeket. Jól látható, hogy a témakörökkel a gyermeki lét teljességét igyekszik visszaadni. Szép példa a témái közül a születés és annak altémái: a fogantatás és a terhesség, a szülés és a császármetszés, mely napjainkban is meghatározó a hétköznapi beszédben. Igaz itt elsősorban annak köszönhetően jelennek meg, hogy a szerző ezeket a kategóriákat tudta a fellelt és elemzett források segítségével elkülöníteni (ez mellesleg semmit sem von le az elvégzett munka értékéből).

7. Sajnálatos, hogy több helyen is disszertációként hivatkozik szövegére a szerző, mert miközben az eredeti „kézirat" valóban a szerző disszertációja, az olvasó már könyvet tart a kezében és nem hagyományos értelemben vett doktori értekezést.

8. Ez lényegében véve már a Köszönetnyilvánítás fejezetében is megjelenik, amikor elmeséli a szerző, hogy milyen külföldi képtá rakba jutott el ösztöndíjak segítségével. 
A kötet kétségtelen értékei mellett a legnagyobb hibájának azt tartom, hogy nem szentel elég teret a kép, mint történeti forrás kritikájának, illetve a kritikára adott saját válaszoknak. Somogyvári 2015-ös kötetében (Somogyvári, 2015) is felmerül a kérdés - még akkor is ha csak "halványan" -, hogy a képelemzés visszaigazolja-e ha egyáltalán lehetséges, hogy visszaigazolja (!) - az írott forrásokat, ám ő sem ad erre megnyugtató választ.

Endrődy-Nagy Orsolya kötetével kapcsolatban még számtalan dolgot ki lehetne emelni, hiszen az „érdekességek tárháza", de a legnagyobb érdemének mégis a képelemzői munkát tartom. A kutatása és a belőle született írás messze túllép egy disszertáció keretein, mondanivalója szétfeszíti annak terjedelmi korlátait és sokkal inkább egy "klasszikus" nagymonográfiára emlékeztet.

\section{Szakirodalom}

1. Darvai Tibor (2011): A Tanító című neveléstudományi folyóirat ikonográfiai vizsgálata. 1963, 1970. Iskolakultúra, 6-7. 71-86.

2. Endrődy-Nagy Orsolya (2013a): Középkor és reneszánsz - adalékok egy lehetséges gyermekképi paradigmaváltáshoz. Gyermeknevelés, 1. 63-72.

3. Endrődy-Nagy Orsolya (2013b): Középkori gyermekkép-narratívák? In: Benedek András és Tóth Péter (szerk.): Új kutatások a neveléstudományokban 2012. MTA Pedagógiai Tudományos Bizottsága; ELTE Eötvös Kiadó, Budapest. 267-288.

4. Géczi János és Darvai Tibor (2010): A gyermek képe az 1960-1980-as évek magyar nevelésügyi szaksajtójában. Új Pedagógiai Szemle, 3-4. 201-237.

5. Golnhofer Erzsébet és Szabolcs Éva (2005): A gyermekkor narratívái. In: Kelemen Elemér és Falus Iván (szerk.): Tanulmányok a neveléstudomány köréból. Műszaki Könyvkiadó, Budapest. 135-147.

6. Golnhofer Erzsébet és Szabolcs Éva (2012): Narratíva és gyermekkorkutatás. In: Németh András (szerk.): A Neveléstudományi Doktori Iskola programjai. Tudományos arculat, kutatási eredmények. ELTE Eötvös Kiadó, Budapest. 13-22.

7. Kéri Katalin és Varga Attila (2006): Acélos szoszó és 25 méter vörös szőnyeg. Átpolitizált alsó tagozatos tankönyvek 1950-1956 között. Educatio, 3. 553-565.

8. Mészáros György (2014): Szubkultúrák és iskolai nevelés. Narratív, kritikai pedagógiai etnográfia. Gondolat Kiadó, Veszprém. URL: http://mek.oszk.hu/13400/13473 Utolsó letöltés: 2015. április 25.

9. Pukánszky Béla (2001): A gyermekkor története. Múszaki Könyvkiadó, Budapest.

10. Pukánszky Béla (2005): A gyermek a 19. századi magyar neveléstani kézikönyvekben. Iskolakultúra, Pécs.

11. Somogyvári Lajos (2012): Közelítések a portrék és az egyszereplős képek jelenségéhez az 1960-as évek magyar pedagógiai szaksajtójában. Iskolakultúra, 6.14-37.

12. Somogyvári Lajos (2013): A szakmai kommunikáció képi megjelenítései (1960-1970). Neveléstudomány: Oktatás - Kutatás - Innováció, 3. 67-79.

13. Somogyvári Lajos (2015): Ikonográfia a neveléstörténet-irásban. Pedagógiai életképek a hatvanas évekból. Gondolat Kiadó, Budapest.

14. Szabolcs Éva (1999): Tartalomelemzés a gyermekkortörténet kutatásában. Gyermekkép Magyarországon 1868-1890. ELTE Eötvös Kiadó, Budapest.

15. Szabolcs Éva (2011): Gyermekból tanuló az iskolás gyermek, 1868-1906. Gondolat, Budapest. 